\title{
Factors Related to Under Achievement in Science, Technology and Mathematics Education (STME) in Secondary Schools in Rivers State, Nigeria
}

\author{
B. J. Obomanu (Corresponding author) \\ Department of Education Science, University of Port Harcourt, Nigeria \\ Tel: +234-803-763-9676Ｅ-mail: baljek@yahoo.com \\ M. O. Adaramola \\ University of Port Harcourt, Nigeria \\ Tel: +2348023232707_E-mail: omooluwayemisi@gmail.com
}

Received: March 14, $2011 \quad$ Accepted: April 13, $2011 \quad$ doi:10.5430/wje.v1n1p102

\begin{abstract}
We report a research into factors related to underachievement in science, technology and mathematics (STM) education in schools in Rivers State, Nigeria. The study investigated 240 Nigerian secondary school students, 100 parents', 140 STM teachers and 20 government officials from Port Harcourt Metropolis. Five (5) research questions and one hypothesis guided the study. Separate questionnaires were used to collate data from the respondents. Frequencies, percentages, bar chart, mean, standard deviation, variance and analysis of variance were used to answer the research questions and to analysis the result from the hypothesis. The result revealed that most teachers teaching STM related subject are not qualified. They are either higher national diploma (HND) holders or engineers. The result also revealed that students' have a negative attitude towards STM related subject, parents are too-busy to look into students school work at home and above all there is inadequate funding and a significant difference in the influence of the stakeholders on students' performance in STM related subjects. Recommendations were made based on these findings.
\end{abstract}

Keywords: Underachievement; Intellectual capital; Stakeholders; Rivers State, Survey.

\section{Introduction}

The purpose of teaching and learning Science, Technology and Mathematics Education (STME) is specifically to produce three kinds of intellectual capital:

Scientists and engineers who will continue the research and development that is central to the economic growth of our country; technological proficient workers who are capable of dealing with the demands of a science-based high technology workforce and scientifically literate citizens who make intelligent decisions about public policy and who understand the world around them.

Accordingly, effective Science Technology and Mathematics (STM) education is critical to enable students to acquire:

1) The deeper intrinsic value of STM education to shape and define our common life history and culture among others.

2) Appropriate skills; abilities and competences that will enable them contribute meaningfully to the development of the society.

And so, there is the need for basic standard of achievement in preparing students for occupations in a highly scientific and technological environment (Encarta, 2005). Moreover, the world summit for sustainable development (WSSD) recommended that people should be empowered through education to achieve the 3 goals of - employment generation, poverty eradication and value - orientation (Ajeyelemi, 2006).

The culture of globalization has equally engendered the Millennium Development Goals Strategies (MDGS), which seek to address issues on poverty, education, equality, wealth and environment and the Education for All (EFA) goals, to be achieved by year 2015 (Nworgu, 2007).

The tool to achieve all these, depend so much on high achievement of students in STM education. It is however sad to note that Nigerian students do not achieve as high as expected in STM to meet the challenges of the nation in this era driven by the relentless necessity for scientific and technological advance. Evidence from literature showed that 
Nigerian students do not perform well in STM related subjects such as Further Mathematics, Chemistry, Biology and Mathematics in internal and external examination. (Chukwuneke and Nwachukwu 2005, Ajagun 2006) This is further corroborated by the West African Examination report of 2006, which showed a high failure rate. Same was the result of the junior secondary (JSS) level, as the analysis of integrated science result of some state government controlled Junior Secondary Schools in Jos North Local Government Area of Plateau state in Nigeria for five consecutive years echo a dismal message of lack lustre performance (Ozaji, 2008).

\section{Research Problem}

The report of Shelter Right Initiative clearly stated that Nigeria trailed behind other West African countries for nine consecutive years in STM academic performance (Olubusuyi, 2003). According to Uzoechi (2004), students do not only perform poorly at the cognitive level, they also perform badly at the affective and psychomotor domains respectively. And to the extent that it is difficult to have a good number of candidates with enough credits to secure admission at higher levels of STM disciplines.

Furthermore, mathematics achievement has never fared better, and has affected subjects like physics and chemistry adversely. WAEC (2006) noted that the marks lost by each physics students as a result of poor knowledge in mathematics accounts for fifty percentages (50\%) of the marks lost for errors in that subject.

Akpan (1998) identified poor knowledge of mathematics as one of the major problems militating against students' progress in chemistry. While Ndioho (2007) believes that reoccurring poor performances recorded in biology is due to students' inability to understand some abstract concepts in that subject. In another breath, Azuka (2000) described mathematics as the queen or servant of the sciences and to that extent, the poor performance in this subject has negatively influenced the learning Science, Technology and Mathematics Education (STME) in schools in Nigeria (see table 1 being the statistics of students' performance in some science subjects for 5 years May/June (2000 - 2004) West African School Certificate Examination in Nigeria as appendix 1)

Accordingly, there is a growing public concern over this unimpressive performance and therefore expedient to understand the problems and challenges facing STM subjects as to suggest appropriate remedies for improved performance. The question however remains, what factors are contributing to this underachievement in Science, Technology and Mathematics Education in Nigeria?

\section{Purpose of Study}

The purpose of this study is to investigate the major factors contributing to underachievement in STM Education in Nigeria. Specifically the objectives therefore are to:

1) Find out the major factors affecting teaching and learning of STM related subjects in Nigeria.

2) Estimate the influence of some major stakeholders on the teaching and learning of STM related subjects in Nigeria

\subsection{Research Questions}

To achieve the objectives of this study, the following research questions were posed:-

1. Are STM teachers in sampled schools qualified and adequate?

2. What are the students' attitudes towards STM related Subject?

3. To what extent do home base factors contribute to students' poor performance in STM related subjects?

4. Does government provide adequate facilities for the teaching and learning of STM related subjects in schools?

5. What influence do the combined variables above have on the performance of students in STM related subject in Nigerian schools?

\subsection{Null Hypothesis}

There is no significant difference in the influence of the above mentioned stakeholders and the performance of students in STM related subjects in Nigerian schools.

\section{Methodology}

This was a survey, and the populations for the study were all STM teachers, SS2 students, parents and Ministry of Education officials in Rivers State. A sample of 500 persons participated in the study. Through simple random sampling; 240 secondary schools students' 140 STM teachers, 100 parents and 20 officials of the Ministry of Education Rivers State responded to the instrument. 


\subsection{Instrumentation}

The research instruments were modified versions of Odogwu (2002) students' questionnaire containing 20 items associated with major causes of students' poor performance in STM related subjects and teachers method of teaching. That of the Teachers' consisting of 50 items investigated the availability of STM materials and equipment in the sampled schools. Parents' questionnaire of 10 items, focused on home environment, students' study habits, learning materials etc. While that of Ministry of Education officials' as stake holders was of 20 items focused on staff position, material supplies and subventions for STM subjects, in-service/workshops among others. All questionnaires were constructed on a 4 point likert - type scale as: strongly agree $=\mathrm{SA}$, agree $=\mathrm{A}$, disagree $=\mathrm{D}$ and strongly disagree $=\mathrm{SD}$. There was a trial testing to improve the content validity. While a method of test retest was used to ascertain their reliabilities. Results obtained were $0.82,0.90,0.78$ and 0.86 respectively. In this study a criterion mean of 2.50 was established and accordingly used for decision making.

\subsection{Data analysis}

The research questions were answered using percentages, frequencies, bar-charts means and standard deviations. The hypothesis was tested at 0.5 level of significance using one-way analysis of variance.

\section{Results and Discussion}

The results of the study are presented below.

\subsection{Research question one: Are STM teachers in Nigerian schools adequate and qualified?}

Table 2 (see appendix 2) presents a picture of holders of at least a degree in the Pure Sciences, Technology and Mathematics related and Education as qualified teachers, and holders of NCE in (STM), HND in (STM), B.Sc. in Engineering and the Pure Sciences, Technology and Mathematics as unqualified. Further illustration in fig.1(see appendix 3), gave clear indication that no holder of National Certificate in Education (NCE) in STM is currently teaching at the senior secondary classes in the sampled schools. However, most STM teachers possess Higher National Diploma (HND) in STM, B.Sc in Engineering and B.Sc in the pure Sciences, Technology and Mathematics (STM). These categories of teachers who are not professionally qualified to teach STM subjects constitute about $64.3 \%$. Meanwhile, teachers who possess B.Sc (Ed) and B.Ed in pure Science, Technology and Mathematics (STM) and those with B.Sc. (Hons) combined with Post Graduate Diploma in Education (PGDE) and considered as professionally qualified, constitute just $35.7 \%$ of the total workforce in the sampled schools. In specific terms, Higher National Diploma (HND) holders in STM constitute the highest proportion (28.6\%) of STM teachers.

To analyze the effectiveness of these teachers' years of experience, class size and weekly workload were taking into consideration. Data analyzed revealed that only $35.7 \%$ of the serving teachers have less than 5 years experience. Meaning that, most of the teachers in the sampled schools have had some reasonable level of experience. In specific terms, $28.6 \%, 7.1 \%, 28.6 \%$ have served between 6 to 16 years and above, given an aggregate of $64.3 \%$. In terms of class size, $71.4 \%$ of the teachers handled classes below 40, a figure that approximates the national standard of 35 per teacher. In effect, within the sampled schools there were few cases of teacher/student ratio beyond normal standard.

\subsection{Research Question 2: What are the students'attitudes towards STM related disciplines?}

From data analysis in table 4(appendix 5), items 2 \& 5 with gender related statements had means of 4.3 and 3.8 respectively. These values were above the criterion mean of 2.5 showing an agreement that gender affects or influences students' attitudes toward the study of Science, Technology and Mathematics related disciplines. The negative statements $6,7,8$ were accepted by the students, while the positive statements $1,3,4$ and 10 were scored below the standard reference mean 2.5,boiling down to the fact that students' have negative attitude towards STM related subject.

Further rating of the students' activities in the class, table 5 (appendix 6) revealed their attitudes. In the table, the activity items were 3, 4,6,7,9 and 10. Out of these only items 4 and 9 attracted a rating above the standard reference mean of 2.50. Indicating in general terms that the students were not active participants in STM classes more so, the passive activities (1, 2, 5 and 8) were all rated above the standard reference mean of 2.50 .

5.3 Research Question 3: To what extent do home base factors contribute to students' poor performance in STM related subject?

In table 6 (appendix 7), contributing factors to students' poor performance in STM subjects; such as items 1, 2,3,4,5 and 8 were rated above the standard reference mean of 2.50 given a clear indication of acceptance. However, items 6, 7, 9 and 10 were not considered as contributing factors as perceived by the respondents. In effect, academic status of parents, students poor feeding, Parents ill health and attendance to PTA meetings are no justifications for lack luster performance in Science, Technology and Mathematics related disciplines. 
5.4 Research Question 4: Does government provide adequate and sufficient resources for the teaching and learning of Science, Technology and Mathematics related disciplines in schools?

In table 7 (appendix 8), Items 1, 3,4,7,8 and 10 attracted ratings above the criterion mean of 2.50, suggesting that Rivers State Ministry of Education officials agreed to the statements such as, good condition of service and the payment of all their allowances regularly; good STM learning environment in relation to classrooms and laboratories; Proper evaluation of the STM curriculum to check for content coverage from time to time; adequate staffing and regular visits by team of inspectors to monitor the teaching of STM related subjects. What is envisaged therefore, as the major problems were within the areas of proper funding; sponsorship of teachers to regular workshops/seminars to keep them abreast of latest developments; and induction courses by the new STM teachers for integration into the system, provision of STM equipment in the laboratories for demonstrations and learning e.g. computers, models, charts etc and disciplinary actions when erring STM teachers are reported. (Items 1,4,5,8 and 10 were rated below standard reference mean 2.5)

5.5 Research Question 5: What influence do the combined variables have on the performance of students in STM related subject in schools?

In table 8 (appendix 9), the highest mean scores were related to teachers and students. Suggesting that when teachers apply the right activities in STM classes and students' develop positive attitude, performance of students abound to enhance in these subjects. Parents' rating was next, indicating their relative influence on students' performance as government influence attracted a mean score of 2.4, indicating a minimal influence.

\subsection{Hypothesis}

HOI; - there is no significant difference in the influence of the above- mentioned stakeholders and the performance of students in STM related subjects in Nigerian schools.

The analysis on table 9 (appendix 10), confirmed a very significant influence stakeholders have on students' performance. This is so, as the calculated $f$ value was higher than the critical $f$ value.

\section{Conclusion}

Tables 2 and 3 provided answers to research question one. It was very clear that, unqualified teachers are virtually in control in the teaching of science technology and mathematics (STM) disciplines in schools. A situation that was perhaps, made possible due to lack of qualified teachers. The gross effect of this has been the consistent poor performance of students in schools.

Table 4 revealed students' negative attitude towards science technology and mathematics (STM) disciplines in agreement with Awosiyan (2006) who investigated problems of teaching and learning in secondary schools in Yobe state and found that students lack interest and have over time developed negative attitude in learning mathematics. As an extension lack of interest and negative attitudes, table 5 indicated lack of active participation of students. An outcome that corroborated the findings of Uzoechi (2004), "that the teaching and learning of science in most of our schools is predominantly by memorization and regurgitation of facts". A situation which no doubt could impede students' development of required scientific skills. Further more, other issues revealed in this study ranged from lack of sponsorship of STM teachers to relevant conferences, workshops and Seminars and in-service training programmes. Moreover, there were existing rooms for laboratories in the schools, but these rooms were not properly equipped in sharp contrast with Adegboye (1993) and Okebukola (2002) views that adequate training in STM requires well-equipped laboratories as an appropriate environment for active learning.

\section{Recommendation}

In view of the above, it is recommended in this study that, all schools should be connected to the internet to enable teachers' and students' access Information in conformity with the rapid demands in this era of globalization. At the same time, STM teachers should be encouraged to attend seminars, conferences and short courses to improve on their pedagogical skills. But above all, enabling environment for qualitative and functional STM education should be established by investing heavily through the provision of laboratory equipment and other facilities required for students' engagement in Science, Technology and Mathematics related disciplines in schools. All these, in addition to recruiting qualified personnel to drive the delivery process to the benefit of the Nigerian society. 


\section{References}

Adegboye, S.O. (1993). The senior secondary school science curriculum and candidates’ performance. An appraisal of $1^{\text {st }}$ cycle of operation. Journal of science teachers association of Nigeria.STAN 28 (1 and 2) $3-12$.

Ajagun G. A (2006). Towards good performance in science education. In E.J. Maduewesi (Ed). Nigerian Journal of Teacher Education and teaching 2 (1) 117-125.

Ajeyelemi (2006). New directions in the Nigerian educational system. "Being the $10^{\text {th }}$ annual public lecture of the Uguogie Irowi foundation held on $8^{\text {th }}$ December at NERDC conference center,Agidingbi, Ikeja, Lagos.

Awosiyan Y.O. (2006) A survey of problems in teaching and learning of mathematics in secondary schools in Damaturu L.G.A. of Yobe state. ABACUS. The journal of mathematics association of Nigeria. (MAN). $31(1) 130$ -141 .

Azuka, B.F. (2000) Mathematics in technological development: Focus on the next millennium - Implications for secondary education. ABACUS. The journal of the mathematics association of Nigeria (MAN) 25 (1) 74 - 83.

Chukwuneke; B.U. and Nwachkwu C.D. (2005) State and future of Education in Nigeria: in J.O. Afe and G.C. Edozie (Eds). Books of abstract and lead papers (58-59) Asaba Nigeria: West and Solomon Publishing Company.

Encarta, (2005) Curriculum, New York Microsoft.

Ndioho, O.F. (2007) Effect of constructivist based instructional model on senior secondary students' achievement in Biology. In Unzewi (Ed). Science Teacher Association of Nigeria. $50^{\text {th }}$ annuiversary conference proceedings (98 101). Sokoto: Heinennann Educational Books.

Nworgu, B.G. (2007) Reforms and quality education in Nigeria. A Keynote address. $19^{\text {th }}$ annual conference of the association for promoting quality education in Nigerian; Rivers State University of Education, Port Harcourt.

Odogun, H.N. (200) Female students perception and attitude to mathematics. A bane to their STM Education. ABACUS. The Journal of Mathematics Association of Nigeria (MAN) 27(1) 24,25.

Okebukola P. (2002). Beyond the stereotype to new trajectories in science teaching special lecture presented at the $43^{\text {rd }}$ annual conference of STAN and CASTME. August.

Okebukola P (2007) Science, technology and mathematics education for sustuianable development. Keynote address. Golden jubilee anniversary conference in Science Teachers Association of Nigeria. Sokoto. August, $23,2007$.

Olubusuyi, P (2003) Education and manpower. Poor teachers’ pay, welfare rebound in students' performance.Vangard Newspaper. Lagos

Ozaji, B.E.(2008) Assessment of conceptual demands of the junior secondary school three integrated science curriculum. In NSIKAK - Abasi U (Ed). The proceedings of the $49^{\text {th }}$ annual science teachers association of Nigeria (STAN) conference 2008. HEBN Publishers. PLC. Page 216 -218

Uzoechi B.C. (2004) Determinant of students questioning attitude in science lessons. Unpublished Ph.D Thesis, University of Nigeria, NSUKKA.

WAEC (2006) Chief examiners report. General certificate of education/school certificate o’ level papers. WAEC. Lagos.

Table 1. WASSCE percentage passes at credit level and above

\begin{tabular}{|c|c|c|c|c|}
\hline Year & Chemistry & Biology & $\begin{array}{l}\text { Further } \\
\text { Mathematics }\end{array}$ & Mathematics \\
\hline 2004 & $39 \%$ & $30 \%$ & $26 \%$ & $34 \%$ \\
\hline 2003 & $51 \%$ & $42 \%$ & $19 \%$ & $18 \%$ \\
\hline 2002 & $43 \%$ & $30 \%$ & $03 \%$ & $35 \%$ \\
\hline 2001 & $30 \%$ & $19 \%$ & $25 \%$ & $37 \%$ \\
\hline 2000 & $32 \%$ & $28 \%$ & $23 \%$ & $33 \%$ \\
\hline
\end{tabular}

Source: WAEC annual report (2000 - 2004) 
Table 2. Analysis in respect to qualifications and adequacy of STM teachers.

\begin{tabular}{|c|c|c|c|c|}
\hline S/N & Qualification & $\begin{array}{c}\text { Number of } \\
\text { Available STM Teachers }\end{array}$ & $\begin{array}{c}\text { Qualified } \\
(\mathbf{\%})\end{array}$ & $\begin{array}{c}\text { Not Qualified } \\
\mathbf{( \% )}\end{array}$ \\
\hline 1 & NCE (STM) & - & - & - \\
\hline 2. & HND (STM) & 40 & - & 28.6 \\
\hline 3. & B.Sc. (Ed)/ B.Ed. & 30 & 21.4 & - \\
\hline 4. & B.Sc. (With PGDE) & 20 & 14.3 & - \\
\hline 5. & B.Sc. Engineering & 20 & - & 14.3 \\
\hline 6. & B.Sc. (STM) & 30 & - & 21.4 \\
\hline & TOTAL & 140 & 35.7 & 64.3 \\
\hline
\end{tabular}

Table 3. STM teachers’ years of experience, class size and weekly workload.

\begin{tabular}{|l|c|c|}
\hline Items & $\begin{array}{c}\text { Total Number of } \\
\text { Sampled Teachers (140) }\end{array}$ & $\begin{array}{c}\text { \% of } \\
\text { Teachers }\end{array}$ \\
\hline Experience & 50 & 35.7 \\
$6-5$ & 40 & 28.6 \\
$11-15$ & 10 & 7.1 \\
16 and above & 40 & 28.6 \\
\hline Class size & 100 & 71.4 \\
$30-40$ & 20 & 14.3 \\
$41-50$ & 20 & 14.3 \\
50 and above & 80 & 57.0 \\
\hline Workload & 60 & 43.0 \\
15 periods and below & - & - \\
$15-20$ & & \\
Above 20 & & \\
\hline
\end{tabular}

Table 4. Mean rating of student' attitude towards STM related Subject

\begin{tabular}{|l|l|l|l|l|}
\hline Item No. & Statements & X & SD & Decision \\
\hline 1. & I like Science, technology and mathematics (STM) Subjects. & 2.0 & 1.9 & $* *$ \\
\hline 2. & (STM) Subjects are more important to boys than girls. & 4.3 & 1.2 & \\
\hline 3. & (STM) Subjects are easy to learn. & 2.1 & 1.3 & $* *$ \\
\hline 4. & (STM) Subjects are interesting. & 2.1 & 1.2 & $* *$ \\
\hline 5. & Boys are naturally better in (STM) subjects than girls. & 3.8 & 1.9 & \\
\hline 6. & You must be very intelligent to learn (STM) subjects. & 4.9 & 1.4 & \\
\hline 7. & (STM) subjects are very demanding. & 5.0 & 1.6 & \\
\hline 8. & (STM) subjects are not very important for my future career. & 5.2 & 1.8 & \\
\hline 9. & I cannot pass any (STM)examination. & 2.3 & 1.8 & $* *$ \\
\hline 10. & I would like to engage in the study of (STM) subjects in future. & 2.2 & 1.2 & $* *$ \\
\hline
\end{tabular}

Standard reference mean $=2.5$; $* *$ Stands for not accepted 
Table 5. STM Activities as perceived by the students

\begin{tabular}{|c|c|c|c|c|}
\hline $\mathbf{S} / \mathbf{N}$ & Items & $\mathbf{X}$ & SD & Decision \\
\hline 1. & We watch our teacher solve problems. & 5.00 & 1.8 & \\
\hline 2. & We copy the teacher in class solution. & 5.00 & 1.6 & \\
\hline 3. & We ask quality questions in the class. & 2.45 & 1.8 & $* *$ \\
\hline 4. & We walk in small groups. & 3.20 & 1.4 & \\
\hline 5. & We solve problems using exactly the teachers method. & 4.60 & 1.3 & \\
\hline 6. & We use other methods to solve problem apart from the teacher's method. & 1.50 & 1.2 & $* *$ \\
\hline 7. & We use other reading materials apart the ones introduced teacher. & 1.50 & 1.3 & $* *$ \\
\hline 8. & We engage in very serious homework. & 5.00 & 1.6 & \\
\hline 9. & We carry out group projects. & 3.80 & 1.5 & \\
\hline 10. & We use to engage in very serious discussions in science, technology and mathematic (STM) class. & 1.50 & 1.3 & $* *$ \\
\hline
\end{tabular}

Standard reference mean $=2.5$; Total number of students $=240$; ** Stands for not accepted

Table 6. Means of possible home base factors contributing to students’ poor performance in STM related subjects, as rated by parents

\begin{tabular}{|l|l|l|l|l|}
\hline S/N & Items & Mean & SD & Decision \\
\hline 1. & Poor scientific environment & 3.40 & 1.9 & \\
\hline 2. & Parents are too-busy to look into students school work at home & 3.30 & 1.5 & \\
\hline 3. & Lack of school materials such as textbooks, writing materials & 3.60 & 1.8 & \\
\hline 4. & Students habitual late coming to school & 3.10 & 1.3 & \\
\hline 5. & Students poor study habits at home & 3.30 & 1.4 & \\
\hline 6. & Academic status of parents & 1.80 & 1.1 & $* *$ \\
\hline 7. & Poor feeding & 2.45 & 1.2 & $* *$ \\
\hline 8. & Negative influence of cyber-café, computer games and peers & 3.20 & 1.6 & \\
\hline 9. & Parents ill health & 1.90 & 1.4 & $* *$ \\
\hline 10. & I attend PTA meeting in my child's school regularly & 2.45 & 1.5 & $* *$ \\
\hline
\end{tabular}

Standard reference mean is 2.5 ; Total number of parents $=100$; ** Stands for not accepted

Table 7. Mean response from River State Ministry of Education officials

\begin{tabular}{|l|l|l|l|l|}
\hline S/N & Item Statement & Mean & SD & Decision \\
\hline 1 & Secondary schools under my supervision enjoy & 2.54 & 1.8 & \\
\hline 2 & Proper funding by government for the provision of STM materials & 2.00 & 1.6 & $* *$ \\
\hline 3 & Adequate staffing. & 2.70 & 1.8 & \\
\hline 4 & Regular visits by team of inspectors to monitor the teaching of STM related subjects & 2.80 & 1.6 & \\
\hline 5 & Attendance to regular workshops/seminars by STM teachers to keep abreast with latest developments & 2.15 & 1.5 & $* *$ \\
\hline 6 & Attendance to induction courses by beginning STM teachers & 2.35 & 1.3 & $* *$ \\
\hline 7 & Proper evaluation of the STM curriculum to check for content coverage from time to time & 2.80 & 1.4 & \\
\hline 8 & Good condition of service and the payment of all their allowances regularly & 2.70 & 1.8 & \\
\hline 9 & Good provision of STM equipment in the laboratories for demonstration and learning e.g. computers, models, charts etc. & 2.30 & 1.6 & $* *$ \\
\hline 10 & Good STM learning environments in relation to classrooms and laboratories. & 2.60 & 1.5 & \\
\hline 11 & Good disciplinary actions when erring STM teachers are reported & 2.25 & 1.7 & $* *$ \\
\hline
\end{tabular}

Standard reference mean $=2.50$; Total number of respondent $=20$; $*$ Stands for not accepted 
Table 8. Mean, standard deviation and variance of responses to research question 5

\begin{tabular}{|c|c|c|c|c|}
\hline S/N & Variable & Mean & SD & V \\
\hline 1 & Government & 2.4 & 1.8 & 3.24 \\
\hline 2 & Parents & 2.9 & 1.6 & 2.56 \\
\hline 3 & Students' attitude & 3.4 & 1.3 & 1.69 \\
\hline 4 & Teachers' classroom activities & 3.4 & 1.5 & 2.25 \\
\hline
\end{tabular}

Standard reference mean $=2.5$; Total number of items in the questionnaire $=10$

Table 9. Summary of Analysis of variance

\begin{tabular}{|l|c|c|c|c|c|c|}
\hline SOURCE VARIANCE & Df & SS & MS & F Calculated & F Critical & Decision \\
\hline Treatment & 3 & 3286.00 & 4428.7 & 2409.1 & 2.84 & $*$ \\
\hline Error & 36 & 66.18 & 1.8383 & & & $\mathrm{P}<0.05$ \\
\hline Total & 39 & 3352.18 & & & & \\
\hline
\end{tabular}

Significant at 0.05 levels

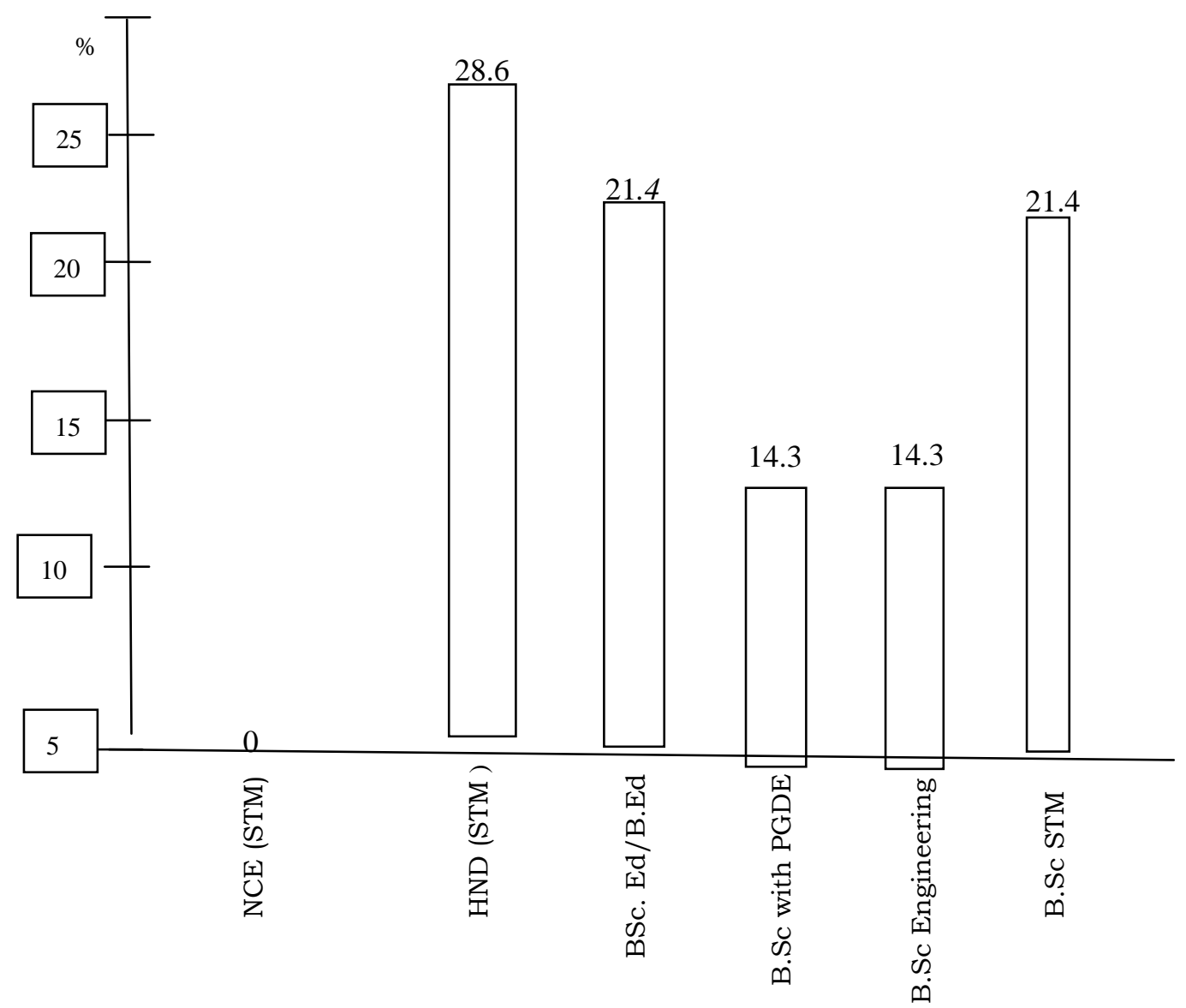

Figure 1. Frequencies and percentages of the available teachers by qualification in the sampled schools 